\title{
The infectivity and pathogenicity of a foot-and- mouth disease virus persistent infection strain from oesophageal-pharyngeal fluid of a Chinese cattle in 2010
}

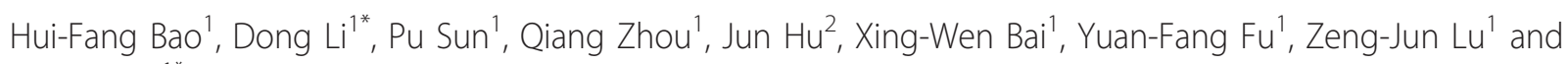
Zai-Xin Liu ${ }^{*}$

\begin{abstract}
Background: Foot-and mouth disease (FMD) is an acute, febrile, and contagious vesicular disease affecting clovenhoofed animals. Some animals may become persistent infected carriers when they contact FMD virus (FMDV), and persistent infected animals are a dangerous factor to cause FMD outbreak.

Findings: 300 OP (oesophageal-pharyngeal) fluid samples were collected from cattle without clinic symptom after one month FMD circulated in 2010 in China. A FMDV strain was isolated when a positive OP sample was passed in BHK21 cell line. The strain, named O/CHN/2010/33-OP, was detected to be O/Myanmar/1998 lineage with VP1 DNA sequence comparison. In order to testify its infectivity, two cattle were challenged with OP fluid and three pigs were put into the same pen for direct contact infection. The result showed that one of the cattle and one of the pigs appeared FMD clinic symptoms respectively. Furthermore, two cattle (three pigs were also put into the same pen for direct contact infection) and three pigs were inoculated with O/CHN/2010/33-OP cell passaged strain. The result showed that one of the challenged pigs appeared FMD clinic symptoms. Two cattle and three pigs in the same pen did not appeared FMD clinic symptoms, but the sera antibody and their OP fluid of two cattle were positive. Meanwhile, the spinal cords of three pigs in the same pen with two cattle were positive detected with multiplex- RT-PCR.
\end{abstract}

Conclusion: The persistent infection strain O/CHN/2010/33-OP has infectivity and pathogenicity to cattle and pigs, and infected cattle may transmit the virus to pigs although its virulence was lower than the circulated strain $\mathrm{O}$ / CHN/Mya98/2010.

Keywords: Foot-and-mouth disease virus (FMDV), Persistent infection strain, Oesophageal-pharyngeal fluid, Infectivity, Pathogenicity

\section{Findings}

Foot-and mouth disease is an acute, febrile, and contagious vesicular disease affecting cloven-hoofed animals. Some animals may become persistent infected carriers when they contact FMDV. Van Bekkum detected FMDV aperiodically from oesophageal-pharyngeal sites of cattle

\footnotetext{
* Correspondence: lidongpaul@yahoo.com.cn; liuzaixin3@hotmail.com ${ }^{1}$ State Key Laboratory of Veterinary Etiologic Biology, Key laboratory of Animal Virology of Ministry of Agriculture, National Foot-and-Mouth Disease Reference Laboratory of China, Lanzhou Veterinary Research Institute, Chinese Academy of Agricultural Sciences, Lanzhou, Gansu 730046, China Full list of author information is available at the end of the article
}

without FMD clinic symptoms and gave a concept "persistent infection" [1]. Dave bred some healthy cattle with FMDV-carried ones for several months and the healthy cattle were infected by the same FMDV strain [2]. Another example is that the origin of FMD circulation in Chinese Taiwan in 1999 was FMDV persistent infection carrier of cattle [3]. Therefore, persistent infected animals are a dangerous factor to cause FMD outbreak.

In recent years, Some Asian countries such as China, Mongolia, Korea, Japan populated FMD which were all caused by the O/Myanmar/1998 lineage strain [4,5]. 
Three hundred OP (oesophageal-pharyngeal) fluid samples were collected from cattle without clinic symptom after one month FMD circulated in 2010 in Xinjiang province of China. A persistent infection strain $\mathrm{O} / \mathrm{CHN} /$ 2010/33-OP was isolated from an OP fluid sample (Figure 1). In this report, we evaluated the infectivity and pathogenicity to cattle and pigs of the strain, and compared the virulence between O/CHN/2010/33-OP and a circulated strain O/CHN/Mya98/2010.

The positive FMDV OP fluid tested with multiplex-RTPCR was propagated in baby hamster kidney (BHK21) cells serially for seven passages, and the supernatants of infected cells were filtered and stored at $-70^{\circ} \mathrm{C}$, named $\mathrm{O} / \mathrm{CHN} /$ 2010/33-OP cell strain $\left(1.3 \times 10^{7.0} \mathrm{PFU} / \mathrm{mL}\right)$. Another cattle tongue FMDV sample was treated with the same way to propagate in $\mathrm{BHK} 21$ cells and stored at $-70^{\circ} \mathrm{C}$, named $\mathrm{O} / \mathrm{CHN} / \mathrm{Mya} 98 / 2010$ cell strain $\left(1.0 \times 10^{7.0} \mathrm{PFU} / \mathrm{mL}\right)$.

Total RNA was extracted from samples, using RNeasy Mini kits (QIAGEN) following the manufacturer's instructions. RNA was reverse transcribed into cDNA and amplified using one step RT-PCR kit(TaKaRa). Two primers 1D2(5'-GCG CTG GCA AAG ACT TTG A- 3') and 1D5 (5'-GAC ATG TCC TCC TGC ATC TGG TTG A- 3') were needed for VP1 gene's amplification. The PCR products were purified and sequenced (Sunny Biologic Company, Shanghai, China).

FMDV type O VP1 gene reference sequences were obtained from Genbank on the National Center for Biotechnology Information (NCBI) website (http://www. ncbi.nlm.nih.gov). Multiple sequence alignments were analyzed and percent identities were showed (Figure 2) using the MegAlign project of DNAStar software package

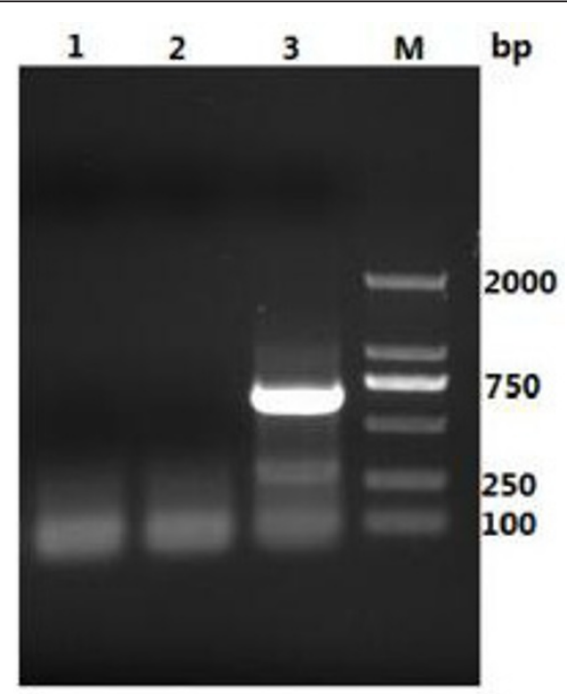

Figure 1 The test result by multiplex-RT-PCR. Line 1 and line 2 were two negative samples; line 3 was positive sample; M was DNA marker ladder. (http://www.dnastar.com). The strains, named O/CHN/ 2010/33-OP and O/CHN/Mya98/2010, were detected to be O/Myanmar/1998 lineage.

Five groups of animals (Official experimental license number:SYXK[Gansu, China]2010-0003)were used (twelve 2-month-old healthy pigs and six 1-year-old healthy cattle, sero-negative for FMDV) in five separate pens to test the infectivity and pathogenicity of O/CHN/ 2010/33-OP and O/CHN/Mya98/2010. All infected animals were observed daily for 14 days post inoculation (d.p.i.) before they were slaughtered to collect OP fluids and lymph nodes and spinal cords for virus detection with multiplex- RT-PCR. The first day was recorded at $24 \mathrm{~h}$ p.i. (Table 1).

In the first group, two cattle (No.134, 184) were injected $0.6 \mathrm{ml}$ positive OP fluid in the surface of their tongue respectively, and three pigs(No.036,039,040) were bred in the same pen. One of the cattle (No.134) developed blister in the foot on the day 8 p.i.. The sera titer of both cattle was 1:1024 on the day 14 p.i. although No.184 did not show clinic symptom. Pig No.036 developed blister on the day 11 p.i.. The sera titer of three pigs were 1:512,1:180, 1:128 respectively on the day 14 p.i.. They were all positive.

In the second group, two cattle (No.3, 146) were injected $2 \mathrm{ml} \mathrm{O} / \mathrm{CHN} / 2010 / 33-O P$ cell strain in the surface of their tongue respectively, and three pigs (No.041, 046, 049) were bred in the same pen. The OP fluids of both cattle were positive on the day 14 p.i. although clinic symptoms did not appear. The sera titer of both cattle was $1: 180$ and $1: 128$ on the day 14 p.i.. Lymph nodes and spinal cords of three pigs were FMDV positive although clinic symptoms did not appear on the day 14 p.i..

In the third group, three pigs (No.029, 032, 033) were injected $2 \mathrm{ml} \mathrm{O} / \mathrm{CHN} / 2010 / 33-O P$ cell strain into one heel bulb and into the ear-root-neck area respectively. Pig No.029 developed primarily blister in the injected foot on the day 4 p.i. and developed secondary blister in another foot on the day 5 p.i.. Its sera titer was 1:180. The sera titer of pigs No.032 and No.033 was 1:512, 1:128 respectively although clinic symptoms did not appear.

In the fourth group, two cattle (No.11, 12) were injected $2 \mathrm{ml} \mathrm{O} / \mathrm{CHN} / \mathrm{Mya} 98 / 2010$ cell strain in the surface of their tongue respectively. Both cattle developed blister.

In the fifth group, three pigs (No.047, 048, 050) were injected $2 \mathrm{ml} \mathrm{O} / \mathrm{CHN} / \mathrm{Mya} 98 / 2010$ cell strain into one heel bulb and into the ear-root-neck area respectively. Only pig No.047 did not appear clinic symptom. Other two pigs developed blister on the day $5 \sim 7$ p.i..

From above experimental result, the persistent infection strain O/CHN/2010/33-OP may infect other cattle 


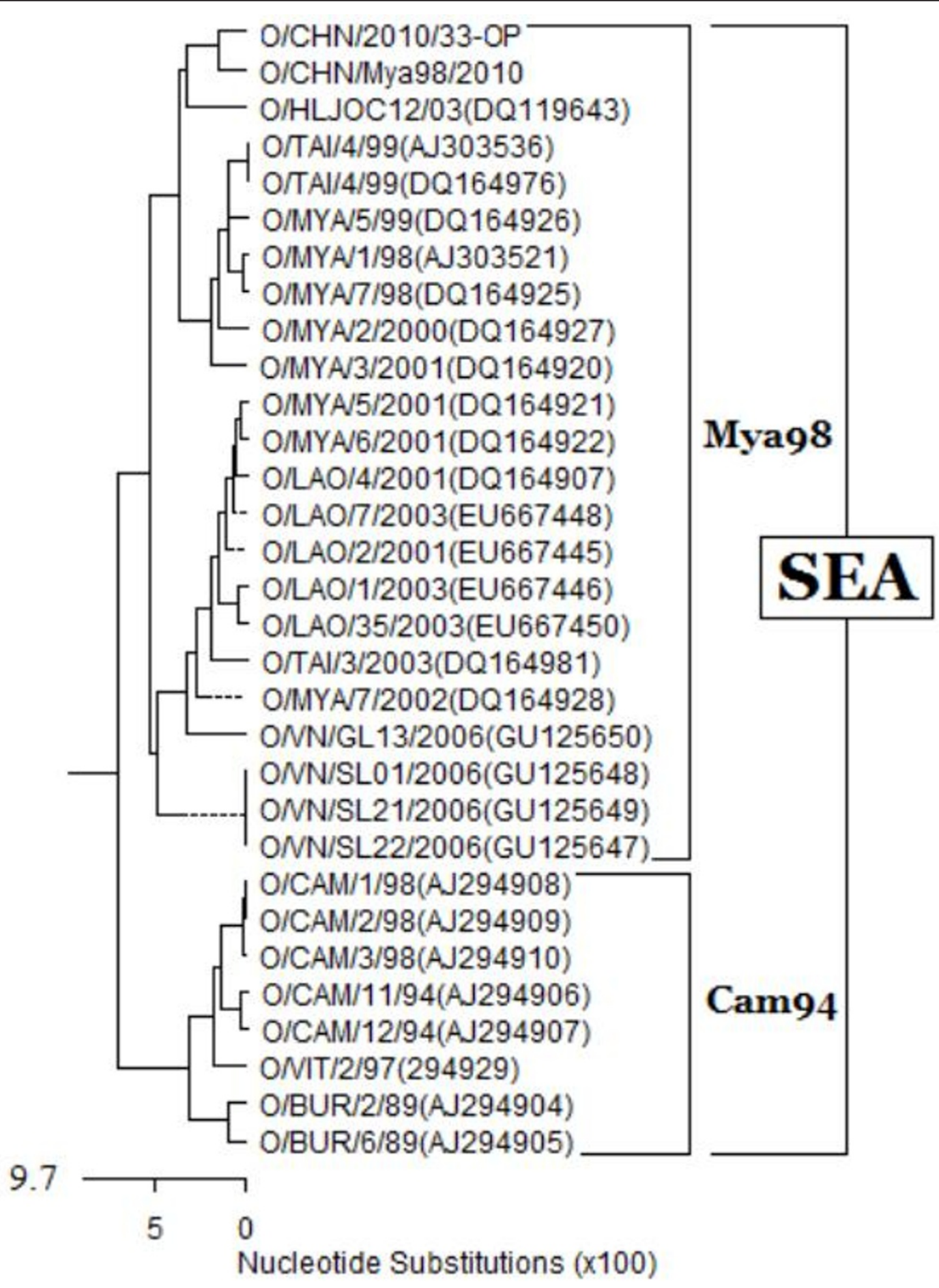

Figure 2 Multiple sequence alignments using the MegAlign project of DNAStar software package.

and pigs. That FMDVs were found out from spinal cords of five direct contact infected pigs (group 1 and group 2) means the virus transmitted from cattle to pigs, and one pig appeared blister means the virus has pathogenicity and can lead to illness of pig. One cattle appeared blister in group 1 when injected OP fluid containing virus. The possible reason was that individual difference may induce some cattle's clinic symptom but 
Table 1 The infectivity and pathogenicity of O/CHN/2010/33-OP

\begin{tabular}{|c|c|c|c|c|c|c|c|c|c|}
\hline Group & Infected strain & Animals & dpi & Clinic symptom & Virus in OP fluid & Virus in lymph nodes & Virus in spinal cords & $\begin{array}{l}3 A B C \\
\text { NSP Ab }\end{array}$ & $\begin{array}{l}\text { Type O } \\
\text { SP Ab } \\
\text { (LPB-ELISA) }\end{array}$ \\
\hline \multirow[t]{13}{*}{ Group 1} & $\begin{array}{l}\text { O/CHN/ } \\
2010 / \\
33-O P \\
\text { OP fluid }\end{array}$ & $\begin{array}{l}\text { cattle } \\
\text { No.134 }\end{array}$ & 8 & + & & & & + & $1: 720$ \\
\hline & & & 14 & + & + & + & & + & 1:1024 \\
\hline & & $\begin{array}{l}\text { cattle } \\
\text { No.184 }\end{array}$ & 8 & - & - & & & + & $1: 360$ \\
\hline & & & 14 & - & - & + & & + & $1: 1024$ \\
\hline & $\begin{array}{l}\text { Direct contact } \\
\text { infection }\end{array}$ & $\begin{array}{c}\text { pig } \\
\text { No.036 }\end{array}$ & 8 & - & & & & - & $<1: 4$ \\
\hline & & & 11 & + & & & & - & $1: 90$ \\
\hline & & & 14 & + & & & + & + & $1: 512$ \\
\hline & & $\begin{array}{c}\text { pig } \\
\text { No.039 }\end{array}$ & 8 & - & & & & - & $<1: 4$ \\
\hline & & & 11 & - & & & & - & $1: 45$ \\
\hline & & & 14 & - & & & + & - & 1:180 \\
\hline & & $\begin{array}{l}\text { pig } \\
\text { No.040 }\end{array}$ & 8 & - & & & & - & 1:6 \\
\hline & & & 11 & - & & & & - & 1:45 \\
\hline & & & 14 & - & & & + & - & 1:128 \\
\hline \multirow[t]{12}{*}{ Group 2} & $\begin{array}{c}\mathrm{O} / \mathrm{CHN} / 2010 / \\
33-\mathrm{OP} \text { cell strain }\end{array}$ & $\begin{array}{l}\text { cattle } \\
\text { No.3 }\end{array}$ & 8 & - & & & & + & $1: 90$ \\
\hline & & & 11 & - & & & & + & 1:90 \\
\hline & & & 14 & - & + & + & & + & 1: 180 \\
\hline & & $\begin{array}{l}\text { cattle } \\
\text { No.146 }\end{array}$ & 8 & - & & & & - & $1: 32$ \\
\hline & & & 11 & - & & & & - & 1:90 \\
\hline & & & 14 & - & + & + & & + & 1:128 \\
\hline & $\begin{array}{l}\text { Direct contact } \\
\text { infection }\end{array}$ & $\begin{array}{c}\text { pig } \\
\text { No.041 }\end{array}$ & 8 & - & & & & - & $1: 4$ \\
\hline & & & 11 & - & & & & - & $1: 4$ \\
\hline & & & 14 & - & & & + & - & 1:16 \\
\hline & & $\begin{array}{c}\text { pig } \\
\text { No.046 }\end{array}$ & 8 & - & & & & - & 1:12 \\
\hline & & & 11 & - & & & & - & 1:6 \\
\hline & & & 14 & - & & & + & - & $1: 6$ \\
\hline
\end{tabular}


Table 1 The infectivity and pathogenicity of O/CHN/2010/33-OP (Continued)

\begin{tabular}{|c|c|c|c|c|c|c|c|c|}
\hline & & $\begin{array}{c}\text { pig } \\
\text { No.049 }\end{array}$ & 8 & - & & & - & 1:4 \\
\hline & & & 11 & - & & & - & 1:6 \\
\hline & & & 14 & - & & + & - & $1: 6$ \\
\hline \multirow[t]{9}{*}{ Group 3} & $\begin{array}{c}\mathrm{O} / \mathrm{CHN} / 2010 / \\
33-\mathrm{OP} \text { cell strain }\end{array}$ & $\begin{array}{l}\text { pig } \\
\text { No.029 }\end{array}$ & 4 & + & & & I & I \\
\hline & & & 5 & + & & & 1 & I \\
\hline & & & 14 & + & & + & + & $1: 180$ \\
\hline & & $\begin{array}{c}\text { pig } \\
\text { No.032 }\end{array}$ & 4 & - & & & I & I \\
\hline & & & 5 & - & & & 1 & I \\
\hline & & & 14 & - & & + & + & 1:512 \\
\hline & & $\begin{array}{c}\text { pig } \\
\text { No.033 }\end{array}$ & 4 & - & & & I & I \\
\hline & & & 5 & - & & & 1 & 1 \\
\hline & & & 14 & - & & + & + & 1:128 \\
\hline \multirow[t]{6}{*}{$\begin{array}{l}\text { Group } 4 \\
\text { (control) }\end{array}$} & $\begin{array}{l}\text { O/CHN/Mya98/ } \\
2010 \text { cell strain }\end{array}$ & $\begin{array}{l}\text { cattle } \\
\text { No.11 }\end{array}$ & 5 & - & & & I & I \\
\hline & & & 8 & - & & & - & $1: 32$ \\
\hline & & & 14 & + & + & & + & $1: 256$ \\
\hline & & $\begin{array}{l}\text { cattle } \\
\text { No.12 }\end{array}$ & 5 & + & & & - & $1: 90$ \\
\hline & & & 8 & + & & & + & 1 \\
\hline & & & 14 & + & + & & + & 1:180 \\
\hline \multirow[t]{9}{*}{$\begin{array}{l}\text { Group } 5 \\
\text { (control) }\end{array}$} & $\begin{array}{l}\text { O/CHN/Mya98/ } \\
2010 \text { cell strain }\end{array}$ & $\begin{array}{l}\text { pig } \\
\text { No.047 }\end{array}$ & 5 & - & & & I & / \\
\hline & & & 8 & - & & & 1 & 1 \\
\hline & & & 14 & - & & + & + & 1:180 \\
\hline & & $\begin{array}{l}\text { pig } \\
\text { No.048 }\end{array}$ & 5 & - & & & / & / \\
\hline & & & 8 & + & & & - & $1: 45$ \\
\hline & & & 14 & + & & + & + & 1:360 \\
\hline & & $\begin{array}{l}\text { pig } \\
\text { No.050 }\end{array}$ & 5 & + & & & / & I \\
\hline & & & 8 & + & & & - & 1:180 \\
\hline & & & 14 & + & & + & + & $1: 360$ \\
\hline
\end{tabular}


some not. This suggested that the persistent infection strain O/CHN/2010/33-OP can infect the same type of animals.

The pathogenicity of the persistent infection strain $\mathrm{O} / \mathrm{CHN} / 2010 / 33-\mathrm{OP}$ was weaker than the popular strain O/CHN/Mya98/2010. Two cattle (group 2) inoculated with the $\mathrm{O} / \mathrm{CHN} / 2010 / 33-\mathrm{OP}$ cell strain did not appear clinic symptom but other two ones (group 4) infected with the popular strain O/CHN/Mya98/2010 developed blister. Meanwhile, only one of three pigs (group 3) infected with the $\mathrm{O} / \mathrm{CHN} / 2010 / 33$-OP cell strain appeared clinic symptom but two of three pigs (group 5) infected with the popular strain O/CHN/Mya98/2010 appeared clinic symptom. The dose and quantity of the inoculated virus was the same. These data demonstrated that the virulence of the persistent infection strain $\mathrm{O} / \mathrm{CHN} / 2010 / 33-\mathrm{OP}$ was lower than the popular strain $\mathrm{O} / \mathrm{CHN} / \mathrm{Mya} 98 / 2010$, which was similar with a previous report about another FMDV persistent infection strain [6].

In brief, the persistent infection strain $\mathrm{O} / \mathrm{CHN} / 2010 /$ 33-OP has infectivity and pathogenicity to cattle and pigs, so it is very important to detect FMD persistent infected animals and eliminate carriers in order to control outbreak of FMD.

\section{Acknowledgements}

This work has been supported by a fund from Ministry of Agriculture of China for animal disease control in border areas (Contract No. 201103008) and a fund from Lanzhou city R \&D programme (2010-1-175).

\section{Author details}

'State Key Laboratory of Veterinary Etiologic Biology, Key laboratory of Animal Virology of Ministry of Agriculture, National Foot-and-Mouth Disease Reference Laboratory of China, Lanzhou Veterinary Research Institute, Chinese Academy of Agricultural Sciences, Lanzhou, Gansu 730046, China.

${ }^{2}$ Xinjiang Animal health supervision Institute, Urumuqi 830060, China.

\section{Authors' contributions}

ZXL was responsible for the research. HFB, DL and PS carried out most of the experiments. DL wrote and revised the manuscript. JH, QZ, XWB, YFF,

ZJL carried out part of the experiment. All of the authors read and approved the final version of the manuscript.

\section{Competing interests}

The authors declare that they have no competing interests.

Received: 4 July 2011 Accepted: 14 December 2011

Published: 14 December 2011

\section{References}

1. Van Bekkum JG, Frenkel HS, Frederiks HHJ: Observations on the carrier state of cattle exposed to foot-and-mouth disease virus. Bull Int Epizoot 1959, 51:917-922.

2. Dawe PS, Sorensen K, Frris NP: Experimental transmission of foot-andmouth disease from African buffalo to cattle in Zimbabwe. Vet Rec 1994, 149:30-31.

3. Chin-Cheng Huang, Yeou-Liang Lin, Ten-Shiang Huang, et al: Molecular characterization of foot-and-mouth disease virus isolated from ruminants in Taiwan in 1999-2000. Vet Microbiol 2001, 81:193-205.

4. Paton DJ, King DP, Knowles NJ, et al: Recent spread of foot-and-mouth disease in the Far East. Vet Rec 2010, 166:569-570.
5. XingWen BAl, PingHua LI, HuiFang BAO, et al: Evolution and molecular epidemiology of foot-and-mouth disease virus in China. Chin Sci Bull 2011, 56(1):1-11.

6. Kaaden O, Eissner G, Bohm HO: Studies on permanent virus excretors in cattle vaccinated and experimentally infected with foot-and-mouth disease. Anim Res Dev 1975, 1:20-33.

\section{doi:10.1186/1743-422X-8-536}

Cite this article as: Bao et al.: The infectivity and pathogenicity of a foot-and-mouth disease virus persistent infection strain from oesophageal-pharyngeal fluid of a Chinese cattle in 2010. Virology Journal 2011 8:536.

\section{Submit your next manuscript to BioMed Central and take full advantage of:}

- Convenient online submission

- Thorough peer review

- No space constraints or color figure charges

- Immediate publication on acceptance

- Inclusion in PubMed, CAS, Scopus and Google Scholar

- Research which is freely available for redistribution 